\title{
A Broadcasting History of Malaysia: Progress and Shifts
}

\author{
Roslina Abdul Latif ${ }^{1}$, Wan Amizah Wan Mahmud ${ }^{1} \&$ Ali Salman ${ }^{1}$ \\ ${ }^{1}$ School of Media and Communication Studies, Faculty of Social Sciences and Humanities, UniversitiKebangsaan \\ Malaysia, Malaysia \\ Correspondence: Roslina Abdul Latif, School of Media and Communication Studies, Faculty of Social Sciences \\ and Humanities, UniversitiKebangsaan Malaysia, Malaysia. E-mail: linalatif1@gmail.com
}

Received: March 14, 2013 Accepted: April 2, 2013 Online Published: April 28, 2013

doi:10.5539/ass.v9n6p50

URL: http://dx.doi.org/10.5539/ass.v9n6p50

\begin{abstract}
This paper aims to delve into the history of broadcasting in Malaysia since the 1980s. We will go down memory lane and see the inception of the first private television station in the country - Sistem Television Malaysia Berhad (STMB) or better known as TV3 which received its licensed in 1983. This paper also looks at the question of ownership as there are strong political and economic ties between the government and the media. While privatization is a goal in the business sector, a free press without government restrictions is not. The government controls the presses and the publishing enterprises throughout Malaysia. Privatization of this television station was one of the initial efforts to transfer media ownership from the government to the private sector. That was in the initial stages of development. Now TV3 sits under Media Prima Berhad, a company listed on the Main Board of Bursa Malaysia and is Malaysia's leading integrated media investment group. It currently owns 100 per cent equity interest in TV3, 8TV, NTV7 and TV9. In addition, Media Prima now owns more than 96.85 per cent equity interest in The New Straits Times Press (Malaysia) (NSTP) Berhad, one of Malaysia's largest publisher which publishes three national newspapers; the New Straits Times, BeritaHarian and Harian Metro. It also owns three radio networks, Fly FM, Hot FM and One FM. This paper also looks at Malaysia's first cable network popularly known as ASTRO. ASTRO is the brand name of the Malaysian direct broadcast satellite pay television service. It transmits digital satellite television and radio to households in Malaysia and Brunei. Astro is an acronym for All-Asian Satellite Television and Radio Operator. Astro is owned and operated by MEASAT Broadcast Network Systems, a wholly-owned subsidiary of Astro All Asia Networks. The other entity under study is Radio Televisyen Malaysia or better known as RTM, a government owned television network.
\end{abstract}

Keywords: history, broadcasting, radio television Malaysia (RTM), Sistem television Malaysia berhad (TV3), Astro all Asia networks (Astro)

\section{Introduction}

Broadcasting has long established itself as an important spatial extension of this nation's historicity. In this day and age, the field of broadcasting is undoubtedly very advanced and vibrant in tandem with technological advancement. The advent of new media with practical and ideological changes of traditional media has impacted social change and subsequently transformed the world communication unification landscape.

The dawn of new media and communication technologies have brought about a profound transformation in the way people communicate and share knowledge and information. These new technologies offer vast new opportunities for public participation and engagement and have the potential to expand media use even further.

It is the main idea of this paper to give an insight at the history, progress and shifts in ownership of the three main broadcasting companies in Malaysia against a backdrop of rapidly accelerating changes in broadcasting acts, globalization and communication that further pushes the envelope of this transformation. This paper also explores the start of the Government Transformation Programme initiated by Prime Minister Datuk Sri MohdNajib bin Tun Haji Abdul Razak.

\section{Newsrooms and Ownership Issues}

\subsection{Sistem Television Malaysia Berhad (TV 3)}

While privatization is a goal in the business sector, a free press without government restrictions is not. The government controls the press, broadcasting houses and the publishing enterprises throughout Malaysia. Strong 
political and economic ties between the government and the media are relationships that have been in place since the beginning of the reporting era in Malaysia.One of the initial efforts to transfer media ownership from the government to the private sector was to privatize Sistem Television Malaysia Berhad (STMB) or better known as TV3. TV3 received its license in 1983. Fleet Group which was UMNO's holding company held 40 per cent of stock making it the only single entity that had control over the station and that also gave them the right to select the remaining ownership partners. TV3 in turn owned MEGA-TV (now a defunct sister company) and Multichannel Multipoint Distribution Service (MMDS formally known as Business Radio Service (BRS)) or Wireless Cable, a cable provider that came in tandem with the deal.

In 1994 a television broadcast license was issued to Melewar Corporation and UtusanMelayu (M) Berhad to operate Metrovision. Tunku Panglima Besar Tunku Tan Sri Abdullah ibni Tuanku Abdul Rahman was Melewar'sIndustrial Group Chairman at the time. Five years into operations, Metrovision was struggling and was "temporarily" off-air by 1 November the same year (1999). In 2002, the Ministry of Finance owned 30 per cent of the consortium that operated Mega TV while a subsidiary firm, Sri Utara, an investment arm of the Malaysian Indian Congress (MIC), a political party in the coalition government, owned another 5 per cent of Mega TV (Lee, 2001). They resumed broadcasting on Thursday 1 January 2004 as 8 TV after being bought by Media Prima Berhad.

All political parties in the coalition government and their investment companies have also interest and control in the major maninstreamnewspapers in Malaysia. When SistemTelevisyen (Malaysia) Berhad (TV3) was issued the country's first and only private television broadcasting license in 1983, their major shareholders then included the Fleet Group, UMNO's holding company, the UMNO-controlled Utusan newspaper publishing group, MIC's Maika Holdings, Daim Zainuddin himself, and the now bankrupt Syed Kechik group.

Fleet Group and later Renong, took control over the then Daim-controlled New Straits Times group. In 1993 a management buy-out through the Malaysian Resources Corporation Berhad (MRCB) took over of the then lucrative TV3 from the other main minority shareholders. This was done with considerable help from the Hong Leong group's QuekLengChan which then placed both TV3 and the NST group firmly in the camp of Finance Minister Anwar Ibrahim at the time. He inturneffectively deployed it to become UMNO's Deputy President, Deputy Prime Minister, and clearly in line to succeed Mahathir as Prime Minister (Gomez, 1990, 1994).

Ownership is obviously an effective way to affirm control over any entity including media establishment. The Malaysian media is controlled by the government through a series of enactments and draconian laws such as the Printing Presses and Publication Act (1984), The Broadcasting Act of 1988 and its successor, Multimedia and Communication Act (CMA) 1998 (amended 2002), The Sedition Act (1948), and Official Secret Act (1972) and the famous Internal Security Act (1960). All these media establishments arecontroled through ownership externally and withinthe media itself all media companies practice self-censorship for all news before print and before broadcast.

Media Prima Berhad is a company listed on the Main Board of Bursa Malaysia and is the leader in Malaysia's integrated media investment group. It currently owns 100 per cent equity interest in TV3, 8TV, NTV7 and TV9. In addition, Media Prima now owns more than 96.85 per cent equity interest in The New Straits Times Press (Malaysia) (NSTP) Berhad, one of Malaysia's largest publisher which prints the NewStraits Times, BeritaHarian and HarianMetro, three highest circulated national newspapers. It also owns three radio networks, Fly FM, Hot FM and One FM (Media Prima Berhad, 2010).

Natseven TV SdnBhd (NTV7) also needs to be mention here that it was licensed in 1998 to Datuk Dr. Effendi Norwawi the Chairman of ENCORP group, which not only owned NTV7 but served as its Chairman. What was the main concern then was that Norwawi was also serving as the Minister of Agriculture at that time. To date, NTV 7 now belongs to the Media Prima Group and known as TV 7.

Content creation; event and talent management are also other cross media interests of Media Prima. They are also the group's leadership position in the Outdoor business represented by Big Tree Outdoor SdnBhd, UPD SdnBhd, Right Channel SdnBhd, Kurnia Outdoor SdnBhd and Jupiter Outdoor Network Sdn Bhd. A strong online presence is also seen through its digital communications and broadcasting subsidiary, Alt Media, via the Lifestyle Portal gua.com.my and the newly launched TonTon.com.my, a cutting-edge video portal with HD-ready. This service not only offers quality viewing experience but customized content and interactivity of social networking. Outside of Malaysia, Media Prima has a controlling stake in TV3 Network Ltd, Ghana's leading private television station (Media Prima Berhad, 2010). 


\subsection{Astro}

All-Asian Satellite Television and Radio Operator or better known as Astro, is the brand name of the Malaysian direct broadcast satellite pay television service. It transmits digital satellite television and radio to households in Malaysia and Brunei.

Astro is a wholly-owned subsidiary of Astro All Asia Networks plc.and operated by MEASAT Broadcast Network Systems. This company was de-listed from the Main Market of Bursa Malaysia Securities Berhad on 14 June 2010, following a successful take-over offer by Astro Holdings SdnBhd, a company owned by TegasSdnBhd and its affiliates and KhazanahNasionalBerhad. It has operations at the All Asia Broadcast Centre located in Bukit Jalil, Kuala Lumpur and MEASAT in Cyberjaya(Astro All Asia Networks, 2011).

Tan Sri AnandaKrishnan, was issued a license in 1995 to operate MEASAT. MEASAT in turn launched ASTRO, Malaysia's digital direct broadcast satellite service. Krishnan is a long-time member of the board of the Bank Negara and operates Malaysia's "Sports Toto" (owned by Berjaya Group currently). He is also estimated with a net worth of over US\$7.4 billion.Malaysia's privately owned FM stations exhibit similar ownership patterns as television, and is largely controlled by Ananda Krishnan. Five of the seven stations are owned by Airtime Management and Programming Sdn. Bhd. (AMP). AMP additionally operates four "FM" services that are available only via digital direct broadcast satellite (ASTRO). AMP is also a division of Krishnan's ASTRO. Not forgetting thatAnanda Krishnan also has control over the telecommunication company Binariang Bhd. that owns two satellites Measat-1, Measat-2 and now Maxis Communications Berhad(S) (Shriver, 2003).

After the launch of the MEASAT-1 satellite as part of Malaysia's commercialization of space, Astro commenced broadcasting in 1996 with an initial bouquet of twenty-two television and eight radio channels, which were its own channels (Astro All Asia Networks, 2011).

\subsection{Radio Television Malaysia}

RTMor Radio Television Malaysia is a government owned television network and it broadcasts from its headquarters in Angkasapuri, Kuala Lumpur. RTM maintains and controls a number of radio and television stations. At present, it runs 6 national, 2 international, 17 states, 11 district radio stations and 2 television channels - TV 1 and TV 2 (RTM, 2010).

When it started transmission on $1^{\text {st }}$ April 1946, RTM was established as Radio Malaya operating out of Singapore. On $31^{\text {st }}$ August 1957 when Malaya received its independence, Radio Malaya was split into two with the original studios in Singapore managed by a new station called Radio SingapurawhileRadio Malaya moved to Kuala Lumpur going on air from the new location on $1^{\text {st }}$ January 1959 (RTM, 2010).

Radio Malaya was later named Radio Malaysia on $16^{\text {th }}$ September 1963 with its signature transmission trademark words Inilah Radio Malaysia (This is Radio Malaysia).Services rendered under Malaysia Television(Malaysia TV) started on $28^{\text {th }}$ December 1963 in the Klang Valley and Selangor. The 10month old Television Singapura which was launched on $16^{\text {th }}$ February 1963 became part of Malaysia Televisyen till 1965 when Singapore broke away from Malaysia (Penyiaran, 1987).

Radio Malaysia later became Rangkaian National (National Channel) on $1^{\text {st }}$ January 1971 and became the nation's first 24 hour radio station. In 1978 RangkaianSatu (Network One) was renamed Malaysia Television Satu. A year later Rangkaian Dua was renamed Malaysia Television Dua. New separate logos for both networks were launched the same year. The following year, Malaysian Televisyen and Radio Malaysia merged to become Radio Television Malaysia, RTM (Penyiaran, 1987).

As of 2007, RTM controlled 17 per cent of television viewing market in the country behind Media Prima with 54 per cent and Astro with 29 per cent. But of late neither RTM or Astro has made the top 20 television programmes (KAS Democracy Report,2008).

The issue of ownership has been a source of discussion at the highest level since its inception. John Lent reported in 1978, the dissatisfaction of MCA vice-president Lee Siok Yew concerning the partisanship and allegiance of Chinese newspaper in the country because they were formed with foreign capital. During that period, the

Chinese newspapers, which were also still independently ownedwere seen as the defender of their rights and often gave question to policiesimplementationed by the government that they deemed unfair to the Chinese community. With ownership of the mainstream newspapers effectively in the hands of the government, the drive for the Chinese newspaper as well as those of other languages to question the government becomes ever more opaque. 
According to Aliran, the journal of social reform, these influences reveal the biases of the Malaysian media. In the 1995 general elections, the daily newspapers carried government advertisements in full but accepted only partial advertisements from opposition parties (Malaysia Press, 2010) and this trend seems to have evolved further. Even so, it could not help the political tsunami of 2008 from taking 'a few' seats from the ruling government.

Many believe that the government does not allow new entrants into the industry despite the fact that they may add to public good. So since they do not believe in the mainstream media owned by the government or by certain sectors of the ruling party, therefore the rakyat has literally moved to alternative means via newspapers, websites, bloggers and social networks. So what defector Party Keadilan Rakyat, Anwar Ibrahim called an "informed citizenry through a contest of ideas," (when he was still Deputy Prime Minister in 2002) is still as elusive as ever in Malaysia.

\section{Malaysian Broadcasting Acts}

As it is with the local press, so, evidently, is it with local television. Indeed like the press, television has seen apparently remarkable changes taking place over the past decade. Television was first introduced in December 1963 with the help of technical consultants from Canada. The initial set-up comprised a single channel national network, under the control of the Radio Television Malaysia (RTM) or the Department of Broadcasting which was one of three departments under the control of the Ministry of Information. In October 1969 a second channel was launched, also under the direct control of the Ministry of Informationand guided by the same directives as those which governed the operations of the first channel (Karthigesu, 1991). These directives, which have remained virtually unchanged also have shaped the broadcasting policy:

1) To explain in depth and with the widest possible coverage the policies and the programmes of the government in order to ensure maximum understanding by the public

2) To stimulate public interest and opinion in order to achieve changes in line with the requirement of the government

\subsection{Broadcasting Act of 1988}

The Broadcasting Act 1988 continues to play a vital role in the underdeveloped of Malaysian broadcasting. The act as it stands is both stringent and inflexible, and gives enormous powers on the government to determine the type of television programmes that are made available to the Malaysian public. The introduction of the act in 1988 was clearly in anticipation of the further commercialization of broadcasting, especially television. Indeed, in the midst of the supposed 'deregulation' of broadcasting, the broadcasting act now gives the minister of information virtually total powers to determine who will and will not broadcast and the nature of the broadcast material. Under the act, any potential broadcaster would need to apply for a license from the minister beforehand. On paper, this means that one individual has the power to decide. Further, part III, section 10, subsection (1) of the act emphasis added), states that 'it shall be the duty of the licensee to ensure that the broadcasting matter by him complies with the direction given, from time to time, by the minister. The October 1996 amendments made to this already stringent piece of legislation were aimed at taking into account the introduction of new services, such as cable and satellite television, satellite radio, pay-TV and video-on-demand.

\subsection{The Finas Act}

The National Film Development Corporation Act (FINAS) 1981 is specifically to cover technological changes that had taken place in the film industry. The act, amended in 1984 among other things widens the definition of film to incorporate video tapes, video discs, laser discs, and video compact discs. With this broad classification, officials can exercise control over and act on people who are found violating certain provisions of the act. Under the act, anyone who possesses three or more copies of the same film is deemed to be involved in the film circulation and therefore is required to apply for a distribution permit.

\subsection{Multimedia and Communication Act (CMA) 1998}

After 10 years in commission, the Broadcasting Act of 1988 was changed to the Multimedia and Communication Act (CMA) 1998. To date it has been amended twice, once in 2002 and again in 2004 (the Communications and Multimedia Content Forum of Malaysia, 2004). After the changes were made, the scope and coverage for this act were strictly for Direct to Home (DTH) subscription broadcasting and/or video on demand services, weather via satellite or cable, andTerrestrial Free-to-Air TV and Radio.

The main objective of these specific broadcast guidelines is to ensure continued reliable standards of content dissemination by broadcasters by accordance with expectations of audience and internationally recognized good practice of electronic media and journalism. This Code is a manifestation of a paradigm shifts that is inlinedto 
technological advancements in the broadcasting industry. It is therefore compliant with the Content Code its standards and not the other way around whereby content takes precedence over standards. Malaysian Broadcasters recognize that creative freedom carries with it the responsibility of ensuring that not only are the rights of the children are protected but also that of viewers and listeners in general. This compels the upholding of ethical and professional practices in the conduct of their business operations toward fulfilling social responsibility.

In amplification to the general principles and the general guidelines laid out, there are specific guidelines on broadcasting that must be taken into consideration. Content dissemination according to the nature of the broadcasting channel, the likely audience and in certain instances (as in free-to-air television and radio), the time of day.

Classifications and schedulings were also put in place as viewers need adequate information about content to make informed viewing choice based on their personal tastes and standards. As such, broadcasters (excluding radio operators) will provide an indication as to the type of content shown by adopting the following classifications. The broadcasters shall put in efforts to display these classifications at regular intervals of the programme:

\section{Classifications}

$\mathrm{U}$ - suitable for viewers of all ages

PG-14 - Parental guidance when allowing children below 14

PG-18 - Parents/Guardians are strongly cautioned to exercise discretion in permitting young persons below the age of 18 to view this programme without supervision

$18 \&$ above - For those above 18

\section{Schedulings}

Can be shown any time of day

Can be shown any time of day

Can be shown any time after $7.30 \mathrm{pm}$

Can only be shown after $10.00 \mathrm{pm}$

In terms of content, all broadcasters must attempt to provide content that, as far as possible, caters to the various tastes and expectations of multicultural Malaysian viewers and listeners. This is in view of the varied tastes of the Malaysian public. Broadcaster also need to take into consideration other categories such as violence and bad language, religious content, exploitation, advertisements and information, advice and warnings.

\section{Datuk Sri Mohd Najib bin Tun Haji Abdul Razak (2008 - present)}

Datuk Sri Mohd Najib bin Tun Haji Abdul Razakis the sixth and current Prime Minister of Malaysia. Born July 23, 1953, he is the son of Malaysia's second Prime Minister, Tun Abdul Razak. As Prime Mininter, he is also President of the United Malays National Organization (UMNO). Previously, he held the position of Deputy Prime Minister from January 7, 2004 until he succeeded Tun Abdullah Ahmad Badawi.

Najib entered office with a focus to reform domestic economic issues including a political transformation. On his first day as Prime Minister, Najib announced the removal of bans on two opposition newspapers, SuaraKeadilan and Harakahdaily, run by the opposition leader Anwar Ibrahim-led People's Justice Party and the Pan Islamic Party, respectively. This was his as his first actions as Prime Minister. He also released 13 people held under the Internal Security Act, pledging to conduct a comprehensive review of the much-criticized law which allows for indefinite detention without trial. In his speech, he emphasized his commitment to tackling poverty, restructuring Malaysian society, expanding access to quality education for all, and promoting renewed "passion for public service" (Dato' Sri Mohd Najib bin Tun Haji Abdul Razak, 2010).

In accordance to this, Prime Minister Najib has also launced the 1Malaysia campaign on September 16, 2008, calling for the cabinet, government agencies, and civil servants to more strongly emphasize ethnic harmony, national unity, and efficient governance. Although many consider the 1Malaysia drive not a new concept, as a similar movement was started by his father, the late Tun Razak when he was Prime Minister. Najib however has added on eight values of 1Malaysia, they are - perseverance, a culture of excellence, acceptance, loyalty, education, humility, integrity, and meritocracy. A day after the campaign was launched (September, 17, 2008), Najib launched www.1Malaysia.com.my in an effort to communicate with the citizens of Malaysia more efficiently and support the broader 1Malaysia campaign. He has used the site to articulate his political and policy initiatives and to provide a forum for Malaysians to discuss government matters. 1Malaysia also makes extensive use of social media tools such as Facebook and Twitter accounts.

\subsection{Government policies by Dato' Seri Mohd Najib Tun Haji Abdul Razak}

Now as the nation progresses and goes into different transitions of governance under the new leadership, we see changes made and new policies implemented. Under the helm of Datuk Sri Mohd Najib bin Tun Haji Abdul 
Razak that has been in office since 2008, he has introduced ten policies to date.

Since being in office, Najib has launched new policies while strengthening ongoing ones that were implemented by the previous government. These policies are:
1) A viable government
2) Becoming a developed nation
3) Public sector transformation
4) Integrity of civil servants
5) Spurring economic stability
6) Creativity and innovation in stimulating the economy
7) Independence and national integration
8) 1Malaysia concept
9) Malaysia and ASEAN
10) Malaysia and international issues

\section{A Media Transformation Programme?}

On the $13^{\text {th }}$ October 2011, Media Prima announced several senior management appointments within the group. Mohammad Azlan Abdullah, who was the Chief Executive Officer (CEO) of Big Tree Outdoor Sdn Bhd took over from NSTP CEO Datuk Anthony Bujang. The appointment took effect when Datuk Anthony's tenure ended in December 2011. According to a statement released by Media Prima, Azlan who was with Big Tree Outdoor since its inception had played an instrumental in the development and growth of Media Prima. Big Tree Outdoor general manager of sales, Jeff Cheah See Hong took over as company COO fromAzlan. He is said to have played a pivotal role in the growth and expansion of Big Tree Outdoor division since 2002.

Meanwhile Abdul Jalil Hamid has been appointed NSTP's new group editor, responsible in overseeing the group's news and editorial operations encompassing the New Straits Times, Berita Harian, Harian Metro and NSTP e-media (NST, 13 Oct 2011). Abdul Jalil is a veteran journalist with extensive experience including an 18 year stint as a foreign correspondent and Deputy Bureau Chief with Reuters, the global news company. With 25 years' worth of experience under his belt and with strategic communications and media management expertise, he takes over from Datuk Zainul Ariffin Mohammed Isa. Datuk Zainul on the other hand helms the NSTP e-media as the Managing Editor, while heading the New Media Division of Media Prima. His main duties are to spearhead the expansion and operations of Media Prima's media units.

In relation to the appointments, Datuk Mohd Ashraf Abdullah is now the Deputy Group Managing Editor of Media Prima's television and radio networks and editorial operations of TV 3, NTV 7, 8 TV, TV 9, Hot FM, Fly FM and One FM. This is a new position in Media Prima. Before being appointed to this current position, Datuk Ashraf was the group editor of TV3 since 2009. He started his career with the NST in 1988 but left in 2004 for a position as General Manager, Group Corporate Affairs of Golden Hope Plantations Bhd. Media Prima also announced relinquishing the position of the Chief Operating Officer of Primeworks Studio Sdn Bhd position by Farish Pawanteh effective 31 October 2011. This follows her appointment to a senior position at a government department. Farish was instrumental in the successful rebranding of TV 3 and the formation of Primeworks since she started with Media Prima in 2005.

According to Media Prima Chairman, Datuk Johan Jaaffar, the changes were made to strengthen the group's editorial operations with emphasis on alternative platforms such as online, mobile and related products. Datuk Johan also commented that "the editorial appointments reflect our commitment to ensure that our news and editorial operations remain effective given the changing media landscape. The appointments of Azlan and Cheah reflect our strong succession planning in ensuring a smooth handover of responsibilities and operations at NST and Big Tree respectively" (R. Sittamparam, 13 Oct 2011).

When a few members of the press were asked what their thoughts were on the latest appointments and restructurings, that they have termed as the 'media transformation program', the comments received were carefully worded ranging from "I believe the transfers and the changes made were to strengthen the growth and the expansion of the media industries" to "maybe we were not doing enough in terms of what the ruling government wants". This was an interesting observation as the media practitioners believe there were more changes to come and at this point, most of them are just taking the 'wait and see' position. 
It was interesting to see on September 15, 2011, just a month prior to the transfers, Najib promised to repeal a myraid of Malaysia's security laws, many of which have been implemented for decades and integrated into the political and law enforcement infrastructure of the country. The Internal Security Act of 1960 was passed in order to deal with a communist insurgency at the time, allowing police to detain suspects indefinitely. However, this has since been turned into a weapon against whoever is seen as a threat to the government. The Banishment Act of 1959 permits the expulsion of non-citizens and the Emergency Ordinance of 1969 allows two years of detention without trial. The repeal of all these three laws would set drastic limits on the heretofore expensive powers of law enforcement. Najib has also repeal the stricture that requires media companies to obtain a yearly permit, a law widely perceived as an effective gag on the media's reporting (Yang, 2011).

On the surface, these reforms appear to be a great leap forward for Malaysian political freedom. Yet many laws remain in place, some as equally stringent as those repealed. The Sedition Act, the Official Secrets Act and the Defamation Act facilitate imprisonment, while the effects of the repeal of the yearly media permits are severely undermined by the fact that the Malaysian government owns many of the country's largest media outlets as clearly stated at the beginning of this paper. Furthermore, the repeal laws are offset by the government's announcement of two new laws this year, which still allow detainment of suspects under 'revised limits' - the specifics of which are yet to be determined. That upcoming debate promises to be a political free-for-all.

Although there were ideas of setting up a Council for the Malaysian press in the 1970s, over time, different politicians would raise the proposal again and again. In 2001 however, the Malaysian Press Institute at the instigation of the Home Ministry drafted and discussed a Media Council Bill. Section 12 of the Bill lists functions of the Media Council. Some 581 journalists signed a petition stating that opposition to these laws was growing and the advocated that the government create a national press council to regulate the industry (Lee, C. 2001). Apparently, their petition fell on deaf ears because there has not been a council created to review the press laws to date.

\section{Conclusion}

Certainly, media regulations and content controls further assure the media content is scrutinized by the government. While those controls are ostensibly aimed at minimizing destabilizing influences, the government's interpretation, application and enforcement of those restrictions have resulted in a squelching of dissenting political speech. The status quo was assured as voices opposing the then regime were silenced through censorship, fines, imprisonment, litigation or professional censure (Zaharom Nain \& Wang Lay Khim, 2004). Though presently some changes have been made to allow for dissenting voices, especially with the abolishment of the ISA, there is still room for improvement.

Of course the present hierarchies and structures, did not emerge out of nothing but were deliberately created by groups in power to enable them to maintain their power as stated in the background of this paper. History has also shown that human beings in power do not enjoy losing that power and will resist challenges, even if these challenges were accepted as changes that would democratize the society further.

In conclusion, I concur with Zaharom and Wang that attempts to reform media ownership would also most certainly not go down too well with the current circle of media owners in Malaysia who, in many cases are closely linked to politicians and political parties both in the ruling coalition and opposition. Concentration of media ownership - and concentration in the hands of politically affiliated companies and individuals at that - has been the norm in Malaysia.

Media reforms place much importance on the need to disperse ownership, the need to breakdown monopolies and oligopolies. Based on the experiences of the more established capitalist economies, there will be much resistance to such reforms. But despite the resistance, the changes and reforms are necessary. The process of democratization contrary to the myths propagated in Malaysia, does not simply entail looking at the party political practices in a narrow sense. It entails democratizing every major sphere of activity, especially the media.

\section{References}

Astro. All Asia Networks. (2011). Astro. All Asia Networks. Retrieved January 26, 2011, from http://www.astroplc.com/09

Burpee, G., \& Nuvich, A. (1996). Malaysian government expresses concern over music-TV content. Billboard, $108(32), 43$.

Gomez, E. T. (2004). The state of Malaysia: Ethnicity, equity and reform. London: Routledge Curzon. 
KAS. (2008). KAS Democracy Report. Media and Democracy, 11(Draft Version). Retrieved from http://www.kas.de/wf/doc/kas_13571-544-2-30.pdf

Lee, C. (2001). Telecommunications Reforms in Malaysia. Faculty of Economics \& Administration. University of Malaya.

Lim, M. K. (2007). The State of Media Control in Malaysia Source Conference Papers - International Communication Association; 2007 Annual Meeting Centre for Policy Initiatives (CPI) Pusat Initiatif Polisi. Retrieved January 26, 2011, from http://www.cpiasia.org

Media Prima Berhad. (n. d.). Retrieved October 16, 2010, from http://www.mediaprima.com.my/

Montlake, S. (2009, September). Najib walks the Malaysian tightrope. Far Eastern Economic Review, 172(7), 56.

Nain, Z., \& Khim, W. L. (2004). Ownership and control of the Malaysian media. Who owns the media. Southbound Sdn. Bhd. Suite 20F, Northam House.Penang. Malaysia.

Napoli, P. M., \& Yan, Z. X. (2007, March). Michael.Media ownership regulations and local news programming on broadcast television: An empirical analysis. Journal of broadcasting \& electronic media, 51(1), 39. http://dx.doi.org/10.1080/08838150701308010

Press Reference (n. d.). Malaysia Press, Media, TV, Radio, Newspapers - newspaper, television, news, circulation, stations, papers, number, print, freedom, mass media, online. Retrieved October 5, 2010, from http://www.pressreference.com/Ky-Ma/Malaysia.html

RTM. (n. d.). Radio Television Malaysia. Retrieved January 28, 2011, from http://www.rtm.gov.my/rtmnew

Shriver, R. (2003). Malaysian Media: Ownership, Control and Political content. Retrieved October 4, 2010, from http://www.rickshriver.net.pdf

Sittamparam, R. (n. d.). Media Prima announces changes in senior management.

Staff of Nanyang. (2001, May 28). China Press Object to MAC acquisition. BERNAMA the Malaysian National News Agency. $\quad$ Retrieved October 4, 2010, from http://www.accessmylibrary.com/article-1G1-75072994/staff-nanyang-china-press.html

The Malaysian Communications \& Multimedia Content Code. (2004). The Communications \& Multimedia Content Forum of Malaysia.

Yang, C. (2011, Fall). Mirage or Reality?Global Notebook. Harvard International Review, 8-9. 